\title{
Spatial and temporal distribution of methane in an extensive shallow estuary, south India
}

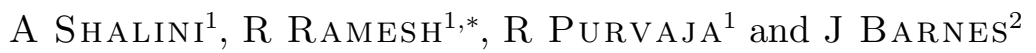 \\ ${ }^{1}$ Institute for Ocean Management, Anna University, Chennai 600 025, India. \\ ${ }^{2}$ School of Marine Sciences and Technology, University of Newcastle-upon-Tyne, \\ Newcastle-upon-Tyne, NE1 7RU United Kingdom. \\ *e-mail: rramesh_au@yahoo.com
}

Sedimentary methane $\left(\mathrm{CH}_{4}\right)$ fluxes and oxidation rates were determined over the wet and dry seasons (four measurement campaigns) in Pulicat lake, an extensive shallow estuary in south India. Dissolved $\mathrm{CH}_{4}$ concentrations were measured at 52 locations in December 2000. The annual mean net $\mathrm{CH}_{4}$ flux from Pulicat lake sediments was $3.7 \times 10^{9} \mathrm{~g} \mathrm{yr}^{-1}$ based on static chamber measurements. A further $1.7 \times 10^{9} \mathrm{~g} \mathrm{yr}^{-1}$ was estimated to be oxidized at the sediment-water interface. The mean dissolved concentration of $\mathrm{CH}_{4}$ was $242 \mathrm{nmol} \mathrm{l}^{-1}$ (ranging between 94 and $501 \mathrm{nmol} \mathrm{l}^{-1}$ ) and the spatial distribution could be explained by tidal dynamics and freshwater input. Sea-air exchange estimates using models, account only for $\sim 13 \%\left(0.5 \times 10^{9} \mathrm{~g} \mathrm{yr}^{-1}\right)$ of the total $\mathrm{CH}_{4}$ produced in sediments, whereas ebullition appeared to be the major route for loss to the atmosphere ( $\sim 63 \%$ of the net sediment flux). We estimated the total atmospheric source of $\mathrm{CH}_{4}$ from $\mathrm{Pulicat}$

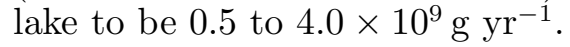

\section{Introduction}

Methane $\left(\mathrm{CH}_{4}\right)$ is an important atmospheric trace gas with a tropospheric residence time of $\sim 10$ years. Mean tropospheric $\mathrm{CH}_{4}$ increased from about $1650 \mathrm{ppbv}$ in the early $1980 \mathrm{~s}$ to around 1800 ppbv in 2005; tropospheric growth was variable throughout the 1990s and since then overall, has slowed significantly (http://cdiac.ornl.gov/ trends/otheratg/blake/blake.html). $\mathrm{CH}_{4}$ currently accounts for about $20 \%$ of anthropogenic greenhouse forcing (IPCC 2001).

$\mathrm{CH}_{4}$ concentrations in temperate estuaries generally far exceed atmospheric equilibrium values and typically are highest at low salinities, decreasing seaward (de Angelis and Lilley 1987; de Angelis and Scranton 1993; Upstill-Goddard et al 2000; Middelburg and Nieuwenhuize 2001); hence estuaries are potentially large sources of atmospheric $\mathrm{CH}_{4}$.
Estuarine $\mathrm{CH}_{4}$ is derived both from external sources, i.e., river and open ocean, and via in situ production in anoxic micro-environments, such as in organic-rich sediments or $\mathrm{O}_{2}$ deficient waters (de Angelis and Lee 1994; Chanton et al 1989; Iversen et al 1987) including turbidity maxima (Upstill-Goddard et al 2000). Estuarine $\mathrm{CH}_{4}$ removal occurs through oxidation in surface sediment (van der Nat et al 1997) and in the water column (de Angelis and Scranton 1993), and emission to the atmosphere (Middelburg and Nieuwenhuize 2001).

Coastal environments including estuaries dominate marine $\mathrm{CH}_{4}$ emissions (Bange et al 1994; Upstill-Goddard et al 2000) but these sources of atmospheric $\mathrm{CH}_{4}$ remain poorly quantified (Middelburg et al 2002); estimates range from $\sim 1$ to $10 \%$ of the total global emissions. Although data from tropical/sub-tropical estuaries are scarce, a few that are available suggest that $\mathrm{CH}_{4}$ emissions

Keywords. Methane emission; spatial and temporal variation; macro-algal zone; estuaries; Pulicat lake. 


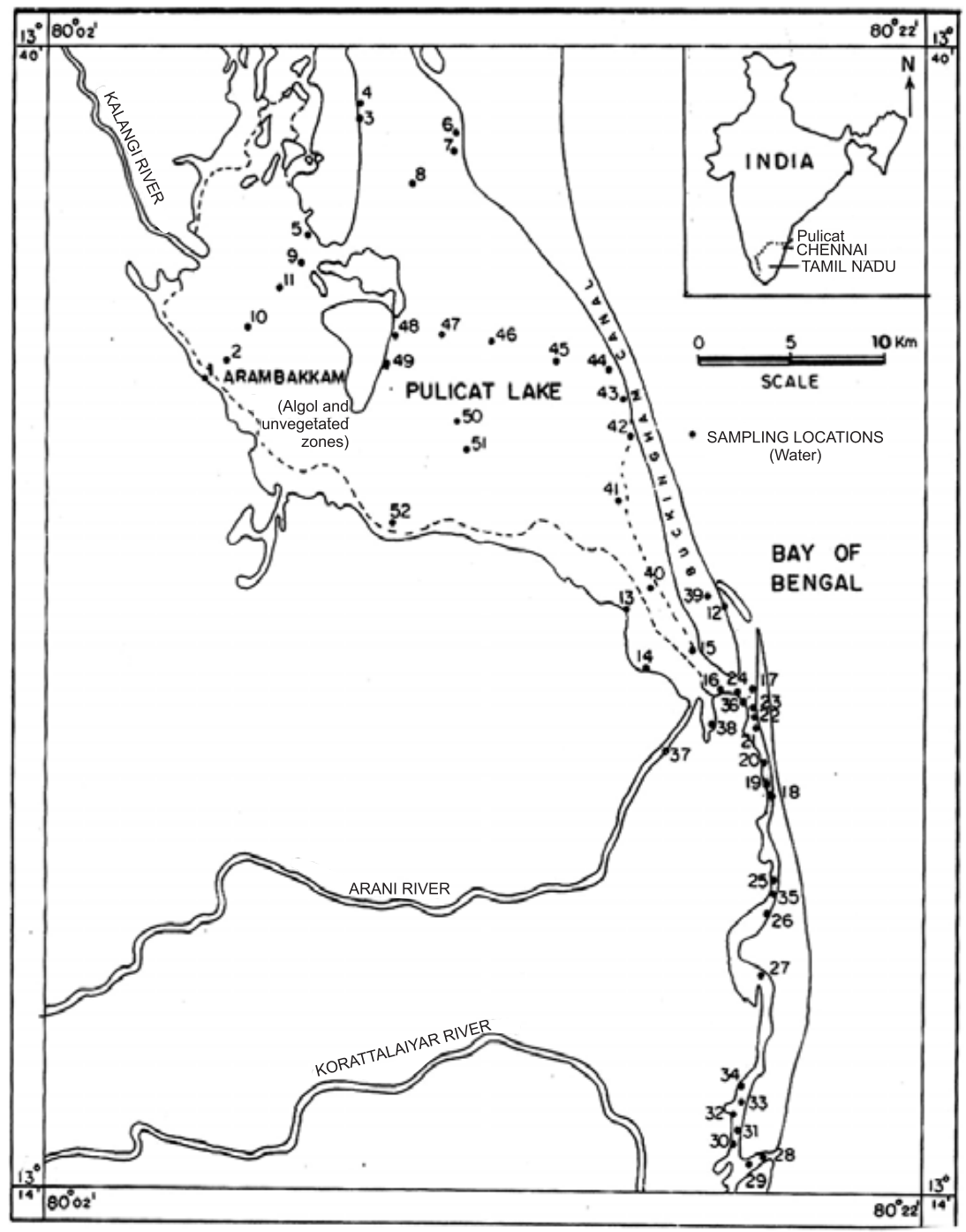

Figure 1. Study area: Arambakkam, Pulicat lake and surface water sampling locations (December 2000).

from polluted tropical estuaries are up to 20 times greater than from unpolluted ones and exceed those from temperate estuaries (Friborg et al 1997; Granberg et al 1997; Ramesh et al 1997; Purvaja and Ramesh 2000). A study of $\mathrm{CH}_{4}$ emissions from coastal wet lands of south India showed that $\mathrm{CH}_{4}$ emission rates from a polluted ecosystem (Adyar Estuary) were twice as high as in an unpolluted mangrove ecosystem (Purvaja and Ramesh 2000).

In this paper, we discuss seasonal (wet and dry season) $\mathrm{CH}_{4}$ emission fluxes from Pulicat lake, an extensive shallow estuary in southeast India; estimated from static flux chamber data and through applying a gas exchange-wind speed relation to surface water dissolved $\mathrm{CH}_{4}$ concentrations, and rates of potential sediment $\mathrm{CH}_{4}$ oxidation determined from core incubations under aerobic and anaerobic incubations. Direct ebullition was estimated on a single occasion. Using these estimates we derive a mean annual $\mathrm{CH}_{4}$ flux for the whole estuary. A generic $\mathrm{CH}_{4}$ cycling budget for Pulicat lake was constructed based on these data, which combine spatial and seasonal $\mathrm{CH}_{4}$ distribution with assessments of fluxes at the sediment-water and air-sea interfaces. This provides the opportunity to discuss the relative contributions of different processes, such as the roles of diffusive and bubblemediated fluxes.

\section{Material and methods}

\subsection{Study area}

Pulicat lake (latitude: $13^{\circ} 24^{\prime} \mathrm{N}$; longitude: $80^{\circ} 02^{\prime} \mathrm{E}$ ) is a shallow $(\sim 1-2.5 \mathrm{~m})$ estuarine ecosystem that provides important support to the local economy via the exploitation of its fish stocks (figure 1). The mixing regime and biogeochemistry of Pulicat lake are highly seasonal. Freshwater input occurs from three small rivers, the Arani, 
Kalangi and Swarnamukhi. Of these, the Kalangi is quantitatively the most important mainly due to its high discharge $\sim 700 \mathrm{~m}^{3} \mathrm{~s}^{-1}$ during the monsoon season. Pulicat lake behaves as a classical estuary with open connection to the sea and salinity increasing seaward. Conversely, due to low freshwater inputs and high evaporation during the dry season (summer) Pulicat lake shrinks from its maximum surface area of $\sim 460 \mathrm{~km}^{2}$ during the wet season to $\sim 250 \mathrm{~km}^{2}$ during summer, with a drop in water level by $\sim 1.5$ metres. At this time the system behaves as a negative estuary; salinities within Pulicat lake exceeding those in surrounding coastal waters (Barnes 2003 unpublished). Occasionally (every two years or so) Pulicat lake is completely isolated from the Bay of Bengal during summer, effectively becoming a hyper-saline lagoon.

Pulicat lake sediments are all generally rich in organic carbon; mean value is $4.5 \pm 0.4 \%$ (Shalini 2002). We estimated seasonal $\mathrm{CH}_{4}$ fluxes at two contrasting sediment sites located about $300 \mathrm{~m}$ apart (Arambakkam; figure 1), selected to span the range of benthic environments found at Pulicat. One site was in an area of exposed silty sand with high populations of burrowing macro infauna including mole crabs, amphipods and polychaetes; we subsequently refer to this as the bioturbated zone. The other site was in an area of silty clay dominated by seagrasses (Halophila ovalis) and green algae (Enteromorpha, Chaetomorpha), and macraofauna; we subsequently refer to this as the macro-algal zone.

\section{$2.2 \mathrm{CH}_{4}$ analysis}

Surface water samples $(0.5 \mathrm{~m})$ for dissolved $\mathrm{CH}_{4}$ analyses were collected in $100 \mathrm{ml}$ serum bottles at 52 locations during December 2000 (figure 1). Samples were immediately inoculated with $0.1 \mathrm{ml}$ of saturated $\mathrm{HgCl}_{2}$ to arrest microbial activity, sealed and stored in the dark in an incubated icebox prior to analysis. In the laboratory, $50 \mathrm{ml}$ sub-samples were transferred to $100 \mathrm{ml}$ sealed vials pre-flushed with ultra pure $\mathrm{N}_{2}$. The vials were then shaken vigorously for 10 minutes to equilibrate $\mathrm{CH}_{4}$ between the two phases (Upstill-Goddard et al 1996), and analyzed by flame ionization gas chromatography (HP 6890); separation was done on 80-100 mesh Porapak $Q$, a $6 \mathrm{ft}$-long column. Column, injector and detector temperatures were 60,100 and $250^{\circ} \mathrm{C}$ respectively, and $\mathrm{N}_{2}$ (flow rate $30 \mathrm{ml} \mathrm{min}^{-1}$ ) was used as a carrier gas (Ramesh et al 1997). Calibration standards were 1.77 ppmv $\mathrm{CH}_{4}$ in $\mathrm{N}_{2}$ (Matheson Inc., USA), and 116 ppmv $\mathrm{CH}_{4}$ in $\mathrm{N}_{2}$ (National Physical Laboratory, New Delhi, India). Details of calculations are described elsewhere (UpstillGoddard et al 1996).

\section{$2.3 \mathrm{CH}_{4}$ flux measurements (Chamber method)}

Sediment $\mathrm{CH}_{4}$ effluxes from the macroalgal and bioturbated sediment sites were estimated with a static perspex chamber $(53 \times 37 \times 71 \mathrm{~cm}, \mathrm{l} \times \mathrm{w} \times \mathrm{h})$ in four seasons: pre-monsoon (September 1999), winter monsoon (December 1999), post-monsoon (March 2000) and inter-monsoon (June 2000). The chamber was secured to an aluminum base collar inserted to a sediment depth of $\sim 10 \mathrm{~cm}$, three hours prior to sampling. A battery-operated air circulation pump with a flow rate of $1.51 \mathrm{~min}^{-1}(\mathrm{M} / \mathrm{S}$ Aerovironment Inc., Monrovia CA, USA) was used to mix the chamber headspace and to transfer headspace samples to glass sampling bottles at 15minute intervals over a 1-hour period. The sampling bottles were fitted with two stopcocks and were initially filled with $\mathrm{N}_{2}$-purged distilled water. Sample collection involved connecting the pump outlet to one stopcock and displacing the water with the sample air. $\mathrm{CH}_{4}$ emission fluxes were determined from the increase in the headspace $\mathrm{CH}_{4}$ mixing ratio with time, and changes in the chamber headspace volume, as determined by continuously monitoring changes in chamber water levels due to tidal height (Ramesh et al 1997; Purvaja and Ramesh 2000; Purvaja et al 2004). Surface water and sediment $(10 \mathrm{~cm}$ depth $)$ temperatures were also measured in situ.

\subsection{Core fluxes}

Perspex ${ }^{\circledR}$ cores $(15 \times 3 \mathrm{~cm}$, length $\times$ diameter $)$ were used to collect sediments from the two different zones. Four replicate cores from each zone were collected to a depth of $10 \mathrm{~cm}$ leaving a $5 \mathrm{~cm}$ headspace to enable flushing with air and nitrogen.

The cores were transferred to the laboratory at in situ temperature in an insulated icebox containing ambient water collected on site. In the laboratory, replicate cores were incubated with either aerobic or anaerobic headspaces to determine potential oxidation rates of $\mathrm{CH}_{4}$. For aerobic incubations, the headspace was flushed with ambient air for 5 minutes and sealed. For anaerobic incubations the procedure was identical except that flushing was with $\mathrm{N}_{2}$ for $\sim 20$ minutes. For each, gas samples $(1 \mathrm{ml})$ were collected at 15 -minute intervals for an hour and analysed for $\mathrm{CH}_{4}$ as described above. Fluxes were estimated from temporal increases in headspace $\mathrm{CH}_{4}$ mixing ratios, as for the incubation chamber. Since $\mathrm{CH}_{4}$ oxidation is generally possible only under aerobic conditions, the anaerobic incubations represent gross $\mathrm{CH}_{4}$ production in each core whereas the aerobic incubations estimate the fraction of $\mathrm{CH}_{4}$ produced that escaped oxidation and subsequently released into the overlying water (Conrad and Rothfuss 1991). 
The difference between the anaerobic and aerobic $\mathrm{CH}_{4}$ flux thus represents the potential rate of $\mathrm{CH}_{4}$ oxidation at the sediment-water interface.

\section{$2.5 \mathrm{CH}_{4}$ emission estimates (air-sea gas exchange models)}

$\mathrm{CH}_{4}$ emissions from the surface of Pulicat lake were also estimated from:

$$
F=k L \Delta C
$$

where $F$ is the interfacial gas flux (mol unit area $^{-1}$ unit time $\left.{ }^{-1}\right), k$ is the gas transfer velocity $\left(\mathrm{cm} \mathrm{hr}^{-1}\right), L$ is the gas solubility, and $\Delta C$ is the $\mathrm{CH}_{4}$ partial pressure difference between the air $(1.7 \mu \mathrm{atm})$ and water phases. Various empirical relationships have been derived for estimating $k$. The two most widely used are those of Liss and Merlivat (1986) and Wanninkhof (1992), which are often assumed to define the upper and lower limits for $k$. Clark et al (1995) derived a relationship for estuaries (using data from the Hudson River estuary), which takes into account turbulence due to interaction with the seabed without wind. For this reason, all three methods are included here to help a comparison with similar studies, although the model developed by Clark et al (1995) for estuaries is probably the most suitable to Pulicat lake. A mean wind speed $\left(4 \mathrm{~m} \mathrm{~s}^{-1}\right)$ obtained from the Chennai harbour buoy data for December 2000 was used in the present calculations.

\subsection{Collection of gas bubbles}

Gas bubbles trapped in the sediments were collected during December 2000 using an inverted glass funnel $(20 \mathrm{~cm}$ diameter $)$ fitted with a silicone rubber septum in its stem between 10 and $20 \mathrm{~m}$ from the location where the static chamber was placed. The sediment was stirred up to collect the gas bubbles into the funnel. The gas was withdrawn using a disposable syringe and transferred into $10-\mathrm{ml}$ Venoject ${ }^{\circledR}$ (Terumo, Belgium) tubes, which were pre-filled with a saturated $\mathrm{NaCl}-$ solution. Excess salt solution was expelled during injection through an additional needle (Krüger et al 2001).

\section{Results and discussion}

\subsection{Spatial variation of dissolved $\mathrm{CH}_{4}$}

Pulicat lake was a source of $\mathrm{CH}_{4}$ to air on all sampling occasions. The mean dissolved $\mathrm{CH}_{4}$ concentration for all samples were $242 \mathrm{nmol} \mathrm{l}^{-1}(n=52)$ with distinct spatial variation, which ranged from
Table 1. Concentrations of dissolved $\mathrm{CH}_{4}$ and associated environmental parameters in the surface water of Pulicat lake in December 2000.

\begin{tabular}{lrrr}
\hline Parameters & Min & Max & Mean \\
\hline Dissolved $\mathrm{CH}_{4}\left(\mathrm{nmol} \mathrm{l}^{-1}\right)$ & 94.14 & 500.62 & 241.91 \\
$\mathrm{SO}_{4}(\mathrm{mM})$ & 2.45 & 16.42 & 9.30 \\
Dissolved oxygen $\left(\mathrm{mg} \mathrm{l}^{-1}\right)$ & 1.92 & 8.57 & 5.31 \\
Standard deviation & $\mathbf{4 5 . 9 4}$ & $\mathbf{2 6 5 . 8 3}$ & $\mathbf{1 1 7 . 0 2}$ \\
\hline
\end{tabular}

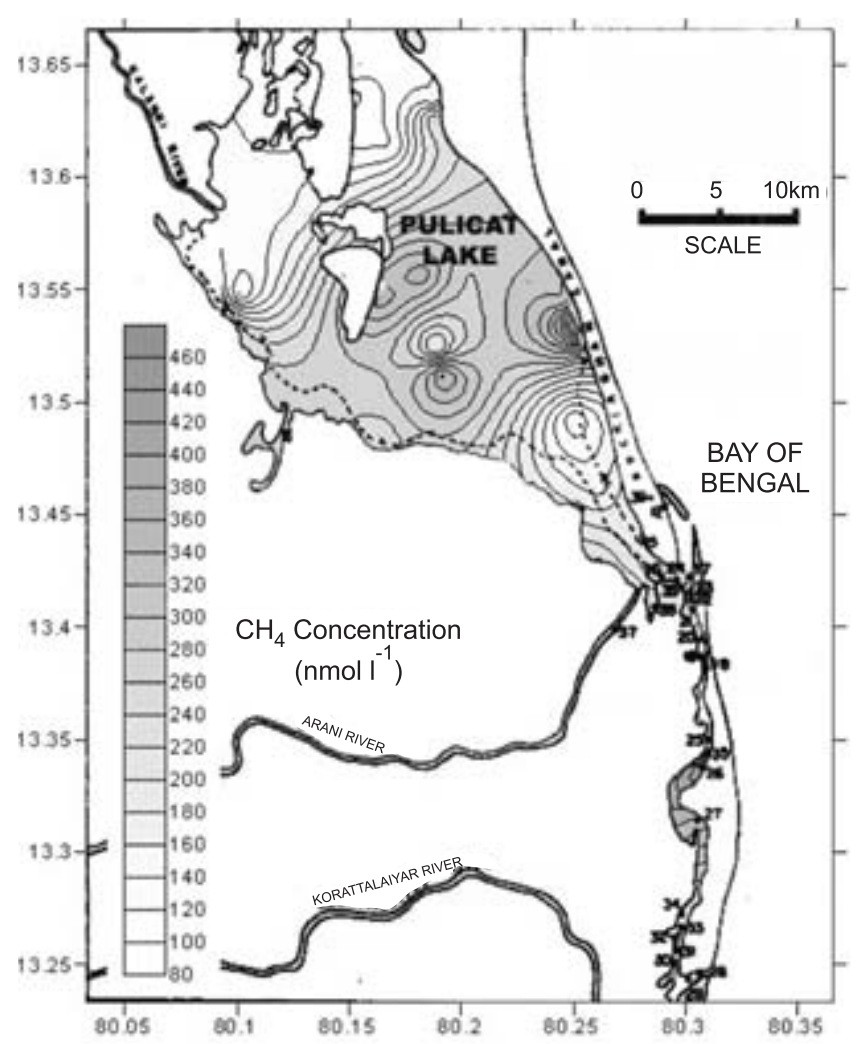

Figure 2. Spatial variation of dissolved $\mathrm{CH}_{4}$ concentrations in the surface water (December 2000).

$94 \mathrm{nmol} \mathrm{l}^{-1}$ to $500 \mathrm{nmol} \mathrm{l}^{-1}$ (table 1 ). Dissolved $\mathrm{CH}_{4}$ concentration maxima therefore appear to be a feature of the centre of the estuary where mixing processes from seawater and freshwater inputs have least impact. The concentration variation was attributed to a variety of influences notably inputs from the Kalangi river which appeared to dilute dissolved estuarine $\mathrm{CH}_{4}$ concentrations. Furthermore, tidal dilution occurs more readily at the Bay of Bengal area of the estuary resulting in lower observed dissolved $\mathrm{CH}_{4}$ concentrations (figure 2).

In the present study, the correlation between salinity and dissolved $\mathrm{CH}_{4}\left(r^{2}=-0.63\right)$ was found to be weak and negative. Similar linear correlation of estuarine $\mathrm{CH}_{4}$ concentrations with increasing salinity were observed by Purvaja and Ramesh (2000) for the Pichavaram mangrove and estuary in south India and in several temperate estuaries 
Table 2. Seasonal and annual flux of $\mathrm{CH}_{4}$ from the Pulicat Lake sediments calculated from temporal increase in headspace mixing ratios using a static flux chamber.

\begin{tabular}{|c|c|c|c|c|}
\hline \multirow[b]{2}{*}{ Seasons } & \multicolumn{2}{|c|}{ Algal zone } & \multicolumn{2}{|c|}{ Bioturbated zone } \\
\hline & $\mathrm{mg} \mathrm{m}^{-2} \mathrm{~h}^{-1}$ & $\mu \mathrm{mol} \mathrm{m} \mathrm{m}^{-2} \mathrm{~h}^{-1}$ & $\mathrm{mg} \mathrm{m} \mathrm{m}^{-2} \mathrm{~h}^{-1}$ & $\mu \mathrm{mol} \mathrm{m}{ }^{-2} \mathrm{~h}^{-1}$ \\
\hline Wet (September 1999) & 1.15 & 71.88 & 1.00 & 62.50 \\
\hline Wet (December 1999) & 0.52 & 32.50 & 0.76 & 47.50 \\
\hline Dry (March 2000) & 0.56 & 35.00 & NA & NA \\
\hline Dry (July 2000) & 0.85 & 53.13 & 1.41 & 88.13 \\
\hline Mean & 0.77 & 48.13 & 1.06 & 66.04 \\
\hline \multicolumn{5}{|l|}{ Annual flux from both the zones } \\
\hline Min & 2.10 & & 3.06 & \\
\hline Max & 4.63 & & 5.68 & \\
\hline Mean & 3.36 & & 4.37 & \\
\hline $\begin{array}{l}\text { Overall mean } \mathrm{CH}_{4} \text { flux from macro-algal } \\
\text { and bioturbated zones }\end{array}$ & 0.91 & 57.08 & & \\
\hline Annual flux from Pulicat lake $\left(10^{9} \mathrm{~g} \mathrm{yr}^{-1}\right)$ & 3.68 & & & \\
\hline
\end{tabular}

(Upstill-Goddard et al 2000; Middelburg et al 2002).

Dissolved $\mathrm{CH}_{4}$ showed a linear correlation with dissolved sulphate $(-0.70)$ in the estuary. Sulphate inhibition of methanogenesis is widely known as a mechanism for reduced $\mathrm{CH}_{4}$ production by marine sediments. Conversely dissolved $\mathrm{O}_{2}$ showed a strong positive correlation with salinity (0.98), which appeared to be a direct function of tidal flushing. The Bay of Bengal exhibited dissolved $\mathrm{O}_{2}\left(5.9 \mathrm{mg} \mathrm{l}^{-1}\right)$ concentrations higher than in the inner zone of the estuary $\left(\sim 2.7 \mathrm{mg} \mathrm{l}^{-1}\right)$. There was a negative correlation $(-0.64)$ between dissolved $\mathrm{O}_{2}$ and $\mathrm{CH}_{4}$ (figure 5) similar to that observed between $\mathrm{CH}_{4}$ and salinity. This may be a direct influence of tidal flushing, which dilutes the estuarine $\mathrm{CH}_{4}$ and increases dissolved oxygen concentrations in Pulicat lake. An additional mechanism could be due to a reduction in $\mathrm{CH}_{4}$ oxidation in the sediments, which could occur due to lower dissolved $\mathrm{O}_{2}$ levels. Table 1 shows the concentrations of dissolved sulfate and oxygen that have a possible influence on surface dissolved $\mathrm{CH}_{4}$ concentrations in Pulicat lake. Tidal flushing is a consistent phenomenon in the Pulicat lake, which plays a major role in the spatial variation of the dissolved $\mathrm{CH}_{4}$ concentration. Although the dissolved $\mathrm{CH}_{4}$ concentrations measured in the Bay of Bengal $\left(50 \mathrm{nmol} \mathrm{l}^{-1}\right)$ during this study were lower than those measured in the estuary proper, they are considerably higher than data published for surrounding coastal waters/oceans (Upstill-Goddard et al 2000) suggesting that the system is also a source of $\mathrm{CH}_{4}$ to the surrounding coastal waters.

\subsection{Temporal variation of $\mathrm{CH}_{4}$ emission from sediments (flux chamber)}

Mean sediment-water-air $\mathrm{CH}_{4}$ fluxes determined with the static chamber are shown in table 2 .

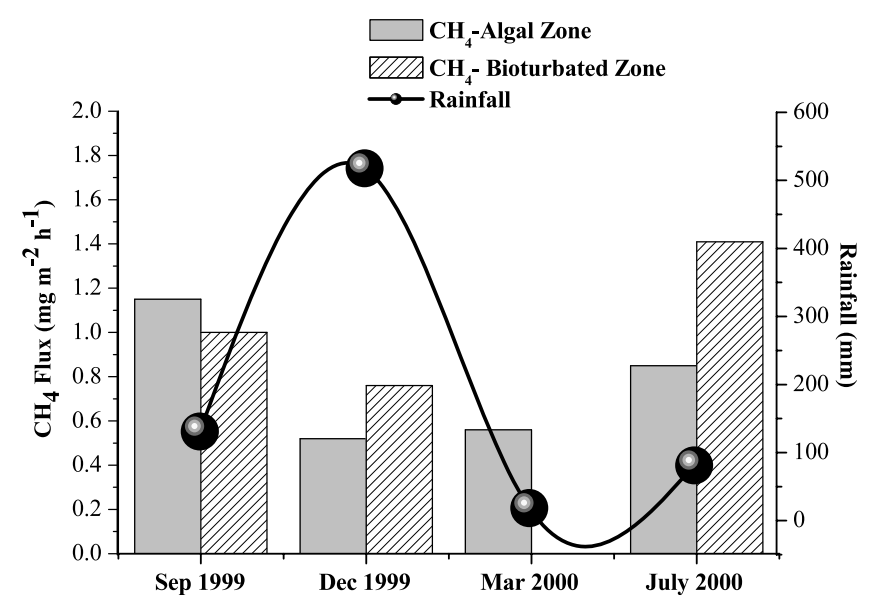

Figure 3. Seasonal variations in $\mathrm{CH}_{4}$ emission and rainfall in the algal and unvegetated zones of Pulicat lake.

At the macro-algal site $\mathrm{CH}_{4}$ emissions varied from $35 \mu \mathrm{mol} \mathrm{m}{ }^{-2} \mathrm{~h}^{-1}$ during the dry season (March 2000) to a maximum of $72 \mu \mathrm{mol} \mathrm{m}{ }^{-2} \mathrm{~h}^{-1}$ in the wet season (September 1999), whereas at bioturbated site $\mathrm{CH}_{4}$ fluxes ranged from $48 \mu \mathrm{mol} \mathrm{m}{ }^{-2} \mathrm{~h}^{-1}$ in the wet season (December 1999) to $88 \mu \mathrm{mol} \mathrm{m}{ }^{-2} \mathrm{~h}^{-1}$ in the dry season (June 2000) (figure 3). This observed seasonal variation in $\mathrm{CH}_{4}$ fluxes could be attributable to a variety of environmental influences notably an increase in ambient temperatures and decreased flushing of the estuary with freshwater. When all seasonal and spatial $\mathrm{CH}_{4}$ flux data are pooled, the mean observed rate is $57 \mu \mathrm{mol} \mathrm{m}^{-2} \mathrm{~h}^{-1}\left(0.91 \mathrm{mg} \mathrm{m}^{-2} \mathrm{~h}^{-1}\right)$. Comparison of the present mean $\mathrm{CH}_{4}$ flux $\left(8.00 \mathrm{~g} \mathrm{~m}^{-2} \mathrm{yr}^{-1}\right)$ with other aquatic ecosystems revealed that the flux rates were comparable to the rates observed in pichavaram mangroves $\left(10.00 \mathrm{~g} \mathrm{~m}^{-2} \mathrm{yr}^{-1}\right)$; higher in highly polluted Adyar estuary and the Sunderban mangroves and lower in all the other estuarine areas. The gross sediment $\mathrm{CH}_{4}$ production was 


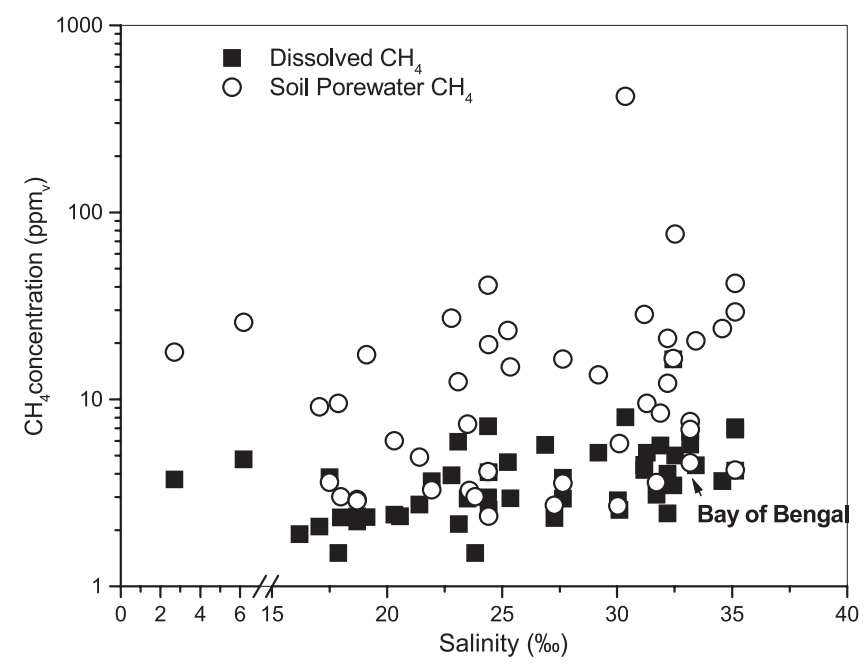

Figure 4. Salinity stratification of dissolved and soil pore water $\mathrm{CH}_{4}$ in Pulicat lake.

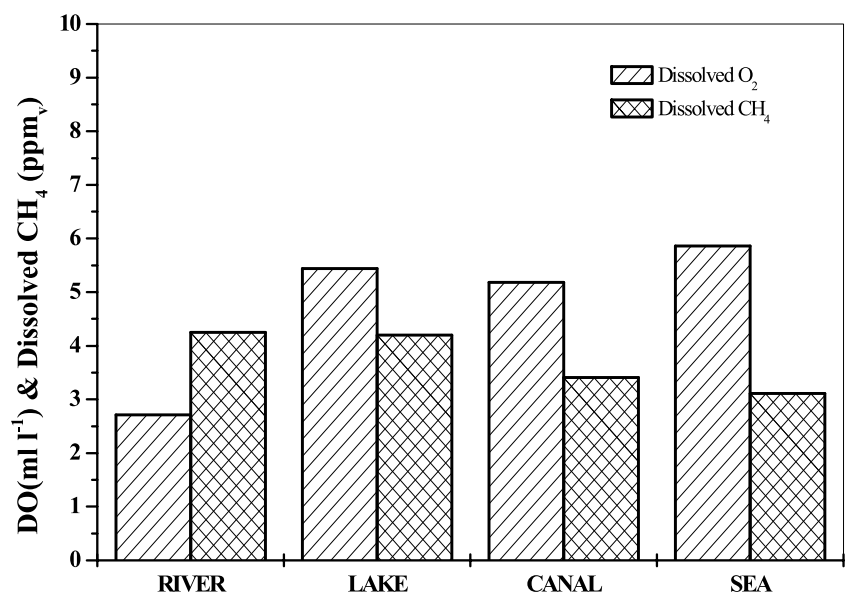

Figure 5. Spatial variation of dissolved oxygen with $\mathrm{CH}_{4}$ in Pulicat lake.

calculated as $3.68 \times 10^{9} \mathrm{~g} \mathrm{yr}^{-1}$ for the entire area of Pulicat lake $\left(460 \mathrm{~km}^{2}\right)$.

\section{$3.3 \mathrm{CH}_{4}$ flux from the sediment cores (aerobic-anaerobic fluxes)}

Aerobic $\mathrm{CH}_{4}$ fluxes in cores from the macroalgal site were $0.26-21.1 \mu \mathrm{mol} \mathrm{m}{ }^{-2} \mathrm{~h}^{-1}$; these were generally lower than the anaerobically measured fluxes of $0.32-37.35 \mu \mathrm{mol} \mathrm{m}{ }^{-2} \mathrm{~h}^{-1}$; hence 19-67\% (mean: 42\%) $\mathrm{CH}_{4}$ oxidation is indicated by these data. At the bioturbated site, potential $\mathrm{CH}_{4}$ oxidation rates were similar to those at the macro-algal site with aerobic flux rates $\left(0.12-6.05 \mu \mathrm{mol} \mathrm{m} \mathrm{m}^{-2} \mathrm{~h}^{-1}\right)$ being lower than the anaerobic flux rates $\left(0.15-22.9 \mu \mathrm{mol} \mathrm{m}{ }^{-2} \mathrm{~h}^{-1}\right)$. Thus potential oxidation rates ranged from 17 to $73 \%$ (mean: $45 \%$ ). These data indicate that $41-$ $45 \%$ of the potential diffusive $\mathrm{CH}_{4}$ flux through the
Table 3. $\mathrm{CH}_{4}$ fluxes calculated using air-sea gas exchange models based on mean surface water dissolved $\mathrm{CH}_{4}$ concentration in Pulicat lake.

\begin{tabular}{|c|c|c|c|}
\hline & Clark & $\begin{array}{l}\text { Liss and } \\
\text { Merlivat }\end{array}$ & Wanninkoff \\
\hline Flux $\left(\mathrm{mol} \mathrm{m}{ }^{-2} \mathrm{~d}^{-1}\right)$ & 0.00018 & 0.000054 & 0.00028 \\
\hline $\begin{array}{l}\text { Flux for the Pulicat } \\
\text { lake }\left(10^{9} \mathrm{~g} \mathrm{yr}^{-1}\right)\end{array}$ & 0.48 & 0.14 & 0.75 \\
\hline
\end{tabular}

sediment-water interface gets oxidized in the oxic surface layers of the Pulicat lake.

\subsection{Bubble ebullition}

One of the main pathways of exchange of $\mathrm{CH}_{4}$ between air and water is ebullition of $\mathrm{CH}_{4}$ from the sediment through the water column (Sebacher et al 1985). The total concentration of $\mathrm{CH}_{4}$ in bubbles was found to be $18 \%$ in the macroalgal $(546-14210 \mu \mathrm{mol})$ and $41 \%$ in the bioturbated zones $(602-33390 \mu \mathrm{mol})$. Accurate quantification of ebullition rates was only achieved successfully in December 2000, where $0.8 \mathrm{ml}$ was collected in 3 hours from an area of $1 \mathrm{~m}^{-2}$.

\subsection{Calculation of emissions using air-sea gas exchange models}

Table 3 shows $\mathrm{CH}_{4}$ fluxes calculated using gas exchange models. A mean wind speed for December 2000 was used $\left(4 \mathrm{~m} \mathrm{~s}^{-1}\right.$; wind speed average obtained from the Chennai harbour buoy data) alongwith the mean observed dissolved $\mathrm{CH}_{4}$ concentrations $\left(242 \mathrm{nmol} \mathrm{l}^{-1} ; n=52\right)$ and an area of $460 \mathrm{~km}^{2}$ to estimate whole estuary fluxes.

The calculated sea-air fluxes of $\mathrm{CH}_{4}$ varied between 0.1 and $0.8 \times 10^{9} \mathrm{~g} \mathrm{yr}^{-1}$. The number calculated using the method of Clarke lies in the middle of these values $\left(0.48 \times 10^{9} \mathrm{~g} \mathrm{yr}^{-1}\right)$ is preferred for this study. This agrees within a range of contemporary data published by Purvaja and Ramesh (2000) for similar environments.

Diffusive $\mathrm{CH}_{4}$ flux data available for the surrounding coastal Bay of Bengal are included here for comparison purposes. $\mathrm{CH}_{4}$ concentration in the surface water is close to atmospheric equilibrium in equatorial areas but increases towards the Ganges/Bramaputra mouth where $\mathrm{CH}_{4}$ flux to the atmosphere reaches up to $30 \times 10^{9} \mathrm{~g} \mathrm{~m}^{-2} \mathrm{yr}^{-1}$ (Berner et al 2003). Adopting the same units for Pulicat lake, based on the model of Clark gives a flux $\sim 1000 \times 10^{9} \mathrm{~g} \mathrm{~m}^{-2} \mathrm{yr}^{-1}$ demonstrating that although $\mathrm{CH}_{4}$ atmospheric emission is small in global terms, on a regional basis Pulicat lake is a significant source of $\mathrm{CH}_{4}$. 
Table 4. Proposed mechanistic $\mathrm{CH}_{4}$ fluxes in Pulicat lake based on data from this study.

\begin{tabular}{|c|c|c|c|}
\hline $\begin{array}{l}\text { Process } \\
\text { no. }\end{array}$ & Flux pathways & $\mathrm{CH}_{4}$ flux & Remarks \\
\hline 1 & $\begin{array}{l}\text { Gross } \mathrm{CH}_{4} \text { production in the sediment } \\
\quad\left(10^{9} \mathrm{~g} \mathrm{~m}^{-2} \mathrm{yr}^{-1}\right)\end{array}$ & 5.34 & $\begin{array}{l}\text { Processes } 2+7 \text { (sum of net } \mathrm{CH}_{4} \text { flux from sedi- } \\
\text { ment into water column }+ \text { calculated potential } \\
\mathrm{CH}_{4} \text { oxidation) }\end{array}$ \\
\hline 2 & Net sediment--water-air flux $\left(10^{9} \mathrm{~g} \mathrm{yr}^{-1}\right)$ & 3.68 & Static chamber measurements \\
\hline 3 & $\mathrm{CH}_{4}$ ebullition as gas bubbles $\left(10^{9} \mathrm{~g} \mathrm{~m}^{-2} \mathrm{yr}^{-1}\right)$ & 1.83 & $\begin{array}{l}\text { Rate of gas bubble ebullition was calculated as } \\
\quad 0.3 \mathrm{ml} \mathrm{h}^{-1}\end{array}$ \\
\hline 4 & Air-sea flux using Clarke's Model $\left(10^{9} \mathrm{~g} \mathrm{yr}^{-1}\right)$ & 0.48 & $\begin{array}{l}\text { Liss and Merlivat Model: } 0.144\left(10^{9} \mathrm{~g} \mathrm{yr}^{-1}\right) \\
\text { Wanninkoff Model: } 0.755\left(10^{9} \mathrm{~g} \mathrm{yr}^{-1}\right)\end{array}$ \\
\hline 5 & $\begin{array}{l}\text { Total } \mathrm{CH}_{4} \text { lost via diffusion and bubbles } \\
\qquad\left(10^{9} \mathrm{~g} \mathrm{~m}^{-2} \mathrm{yr}^{-1}\right)\end{array}$ & 2.31 & $\begin{array}{l}\text { Processes } 3+4 \text { (sum of flux from bubble ebul- } \\
\text { lition and air-sea fluxes) }\end{array}$ \\
\hline 6 & $\begin{array}{l}\text { Calculated } \mathrm{CH}_{4} \text { oxidation in the water column } \\
\quad\left(10^{9} \mathrm{~g} \mathrm{~m}^{-2} \mathrm{yr}^{-1}\right)\end{array}$ & 1.37 & $\begin{array}{l}\text { Processes } 2-5 \text { (difference between net } \mathrm{CH}_{4} \\
\text { efflux from sediment into water and total } \mathrm{CH}_{4} \\
\text { lost via diffusion and bubbles) }\end{array}$ \\
\hline 7 & $\begin{array}{l}\mathrm{CH}_{4} \text { oxidation }(45 \%) \text { from core fluxes } \\
\quad\left(10^{9} \mathrm{~g} \mathrm{~m}^{-2} \mathrm{yr}^{-1}\right)\end{array}$ & 1.66 & $45 \%$ of Process 2 \\
\hline 8 & Loss from system to atmosphere (\%) & 7 & Proc \\
\hline 9 & $\mathrm{CH}_{4}$ lost as bubbles (\%) & 62.80 & $($ Process 5/Process 2) $\cdot 100$ \\
\hline 10 & Oxidation in the water column (\%) & 24.10 & $100-$ Process 8 \\
\hline 11 & $\begin{array}{l}\text { Emission to atmosphere from sediment via water } \\
\text { (\%). Calculated using Clark's air-sea gas } \\
\text { exchange model (diffusive loss) }\end{array}$ & 13.05 & $\begin{array}{l}\text { (Process } 4 / \text { Process } 2) \cdot 100 \text { (remaining } \mathrm{CH}_{4} \\
\text { in the water column: includes bubbles and } \\
\text { diffusion) }\end{array}$ \\
\hline
\end{tabular}

\section{Conclusions}

This study has revealed some interesting insights into mechanisms of $\mathrm{CH}_{4}$ fluxes in Pulicat lake. Table 4 summarizes these findings, based on the flux calculations shown above. The entire estuarine sediment, regardless of habitat, appears to be a consistent source of methane throughout the year producing $\sim 3.68 \times 10^{9} \mathrm{~g} \mathrm{yr}^{-1}$, after oxidation of $\mathrm{CH}_{4}$ at the sediment/water interface which accounts for $\sim 45 \%$ of that. However, only $15 \%$ of the net flux was calculated to be lost through sea-air gas exchange processes suggesting direct ebullition, water column oxidation and outflows to the Bay of Bengal account for the remainder. Bubble ebullition was observed throughout Pulicat on a seasonal basis and was noted to coincide with tidal minima. Collection of bubbles for concentration analysis was easily achieved (mean $=33 \%$ for macro-algal and $41 \%$ for bioturbated zone; $n=10$ ), however the volume was successfully collected without disturbance only on one occasion $\left(0.3 \mathrm{ml} \mathrm{m}^{-2} \mathrm{hr}^{-1}\right.$, December 2000). If this number is tentatively adopted as representative of ebullition rates at Pulicat then, direct loss to the atmosphere through bubble formation would account for $\sim 63 \%\left(2.31 \times 10^{9} \mathrm{~g} \mathrm{~m}^{-2} \mathrm{yr}^{-1}\right)$ of the total $\mathrm{CH}_{4}$ produced in the sediments. Even with the inherent shortcomings of this approach it is clear that direct bubble ebullition is a major source of atmospheric $\mathrm{CH}_{4}$ from Pulicat. Quantitative ebullition data would lead to a considerable upscaling of the $\mathrm{CH}_{4}$ estuarine source strength than that based on diffusive fluxes alone. Adopting the calculated flux rate using Clarke's model $\left(0.48 \times 10^{9} \mathrm{~g} \mathrm{yr}^{-1}\right)$ as a minimum and the measured ebullition rate in addition to Clarke's flux as a maximum we conservatively estimate the total annual atmospheric $\mathrm{CH}_{4}$ source from Pulicat lake as $0.48-2.79 \times 10^{9} \mathrm{~g} \mathrm{yr}^{-1}$ ).

Table 5 shows the results of this study in the context of other similar contemporary data from tropical coastal areas. Our data are in broad agreement with other static chamber measurements but are generally towards the higher-end of the observed range. The notable exceptions are the Adyar estuary in Chennai, India and the Vembanad lake on the west coast of India. The Adyar estuary is heavily impacted by inputs and flow within the river is mainly due to discharge from sewage treatment plants and discharge of sullage and other wastes from numerous storm water outlets (Ramesh et al 1997). Thus, it should be expected that these environments act as a strong source of atmospheric $\mathrm{CH}_{4}$. The Vembanad is an extensive shallow estuary geomorphologically similar to Pulicat (Verma et al 2001) and reported $\mathrm{CH}_{4}$ fluxes are higher than those reported for all other estuaries. From the present study it is clear that extensive estuarine sub-tropical and tropical coastal lagoons represent a potentially significant local source of $\mathrm{CH}_{4}$ to the atmosphere and further work is required to accurately quantify this flux. 


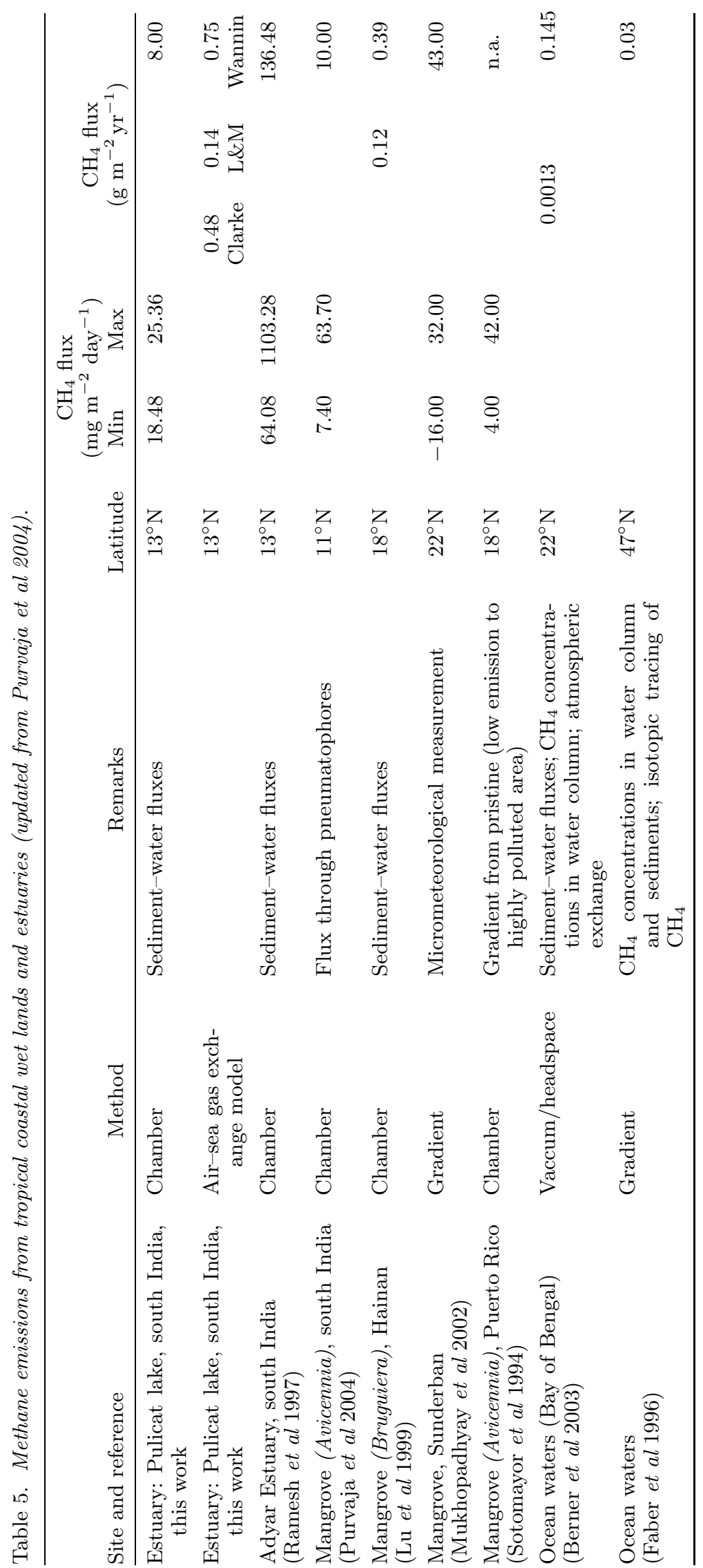




\section{Acknowledgements}

The first author thanks the Council of Scientific and Industrial Research (CSIR), Government of India for providing Senior Research Fellowship to carry out this work. The authors also thank the Indian Space Research Organization (ISRO-GBP) (Grant No. 9/1(16)/97-II) and PR thanks the Department of Science and Technology, Government of India (Grant \#: SR/FTP/ES$59 / 2001)$ for their financial support. RR thanks the Department of Science and Technology, Government of India and the Royal Society, UK (Grant \#: INT/UKNW/P-49/2005) for financial support to a part of this work. We thank Prof. Peter Frenzel of the Max-Planck-Institute for Terrestrial Microbiology, Marburg, Germany and Prof. Rob UpstillGoddard, School of Marine Sciences and Technology, University of Newcastle-upon-Tyne, UK, for critically reviewing this manuscript. The authors thank Ms. K Krithika, IOM, Anna University, Chennai, for her assistance in the preparation of this manuscript.

\section{References}

Bange H W, Bartell U H, Rapsomanikis S and Andreae M O 1994 Methane in the Baltic and North Seas and a reassessment of the marine emissions of methane, Global Biogeochem. Cycles 8 465-480.

Barnes J 2003 Salinity gradient in the Pulicat lake, Unpublished.

Berner U, Poggenburg J, Faber E, Quadfasel D and Frische A 2003 Methane in ocean waters of the Bay of Bengal: Its sources and exchange with the atmosphere; Deep-Sea Res. II 50 925-950.

Chanton J P, Martens C S and Kelley C A 1989 Gas transport from methane-saturated, tidal freshwater and wetland sediments; Limnol. Oceanogr. 34 807-819.

Clark J F, Schlosser P, Simpson H J, Stute M, Wanninkhof R and Ho D T 1995 Relationship between gas transfer velocities and wind speeds in the tidal Hudson river determined by the dual tracer technique; In: Air-water gas transfer: Selected papers from the third international symposium on air-water gas transfer (eds) Jähne B and Monahan E S 785-800, Aeon Verlag and Studio, Hanau, Germany.

Conrad R and Rothfuss F 1991 Methane oxidation in the soil surface layer of a flooded rice field and the effect of ammonium; Biol. Fertil. Soils 12 28-32.

de Angelis M A and Lee C 1994 Methane production during zooplankton grazing on marine phytoplankton; Limnol. Oceanogr. 39 1298-1308.

de Angelis M A and Lilley M D 1987 Methane in surface waters of Oregon estraries and rivers; Limnol. Oceanogr. 32 716-722.

de Angelis M A and Scranton M I 1993 Fate of methane in the Hudson River and Estuary; Global Biogeochem. Cycles 7 509-523.

Faber E, Berner U, Gerling P, Hollerbach A, Stahl W J and Schröder H G 1996 Isotopic tracing of methane in water and exchange with the atmosphere, Energy Convers. Managem. 37(6-8) 1193-1198.
Friborg T, Christensen T R and Sogaard H 1997 Rapid response of greenhouse gas emission to early spring thaw in a subarctic mire as shown by micrometeorological techniques; Geophys. Res. Lett. 24 3061-3064.

Granberg G, Mikkelä C, Sundh I, Svensson B H and Nilsson M 1997 Sources of spatial variation in methane emission from mires in northern Sweden: A mechanistic approach in statistical modeling; Global Biogeochem. Cycles 11 135-150.

Iversen N, Oremland R S and Klug M J 1987 Big Soda Lake, Nevada, 3, Pelagic methanogenesis and anaerobic methane oxidation; Limnol. Oceanogr. 32 804-814.

Krüger M, Frenzel P and Conrad R 2001 Microbial processes influencing methane emission from rice fields; Global Change Biology 7 49-63.

Liss P S and Merlivat L 1986 Air-sea gas exchange rates: Introduction and synthesis; In: The Role of Air-Sea Exchange in Geochemical Cycling (ed.) Buat-Menard P, Reidel, pp. 113-127.

Lu C Y, Wong Y S, Tam N E Y, Ye Y and Lin P 1999 Methane flux and production from sediments of a mangrove wetland on Hainan Island, China; Mangroves and Salt Marshes 3 41-49.

Middelburg J J and Nieuwenhuize J 2001 Nitrogen isotope tracing of dissolved inorganic nitrogen behaviours in tidal estuaries; Estuarine Coast. Shelf Sci. 53 385-391.

Middelburg J J, Nieuwenhuize J, Iversen N, Hoegh N, de Wilde $H$, Helder $W$, Seifert $R$ and Christof $O$ 2002 Methane distribution in European tidal estuaries; Biogeochem. 59 95-119.

Mukhopadhyay S K, Biswas H, De T K, Sen B K, Sen S and Jana T K 2002 Impact of Sundarban mangrove biosphere on the carbon dioxide and methane mixing ratios at the NE coast of Bay of Bengal, India; Atmos. Environ. 36 629-638.

Purvaja R and Ramesh R 2000 Natural and anthropogenic $\mathrm{CH}_{4}$ emission from Coastal wetlands of South India; Environmental Management 27 547-557.

Purvaja R, Ramesh R and Frenzel P 2004 Plant-mediated methane emission from an Indian mangrove; Global Change Biology 10 1-10.

Ramesh R, Purvaja R, Parashar D C, Gupta P K and Mitra A P 1997 Anthropogenic forcing on methane emission from the polluted wetlands (Adyar river) of Madras City, India, Ambio 26(6) 369-374.

Sebacher D I, Harriss R C and Bartlett K B 1985 Methane emission to the atmosphere through aquatic plants; J. Environ. Qual. 14 40-46.

Shalini A 2002 Methane cycling in a natural brackish water lake: A case study on Pulicat lake, South India; PhD Thesis, Anna University, pp. 229

Sotomayor D, Corredor J E and Morrell J M 1994 Methane flux from mangrove sediments along the southwestern coast of Puerto Rico; Estuaries 17(18) 140-147.

Upstill-Goddard R C, Rees A P and Owens N J P 1996 Simultaneous high-precision measurements of methane and nitrous oxide in water and seawater by single phase equilibration gas chromatography; DeepSea Res. I: Oceanographic Research Papers 43(10) 1669-1682.

Upstill-Goddard R C, Barnes J, Frost T, Punshon S and Owens N J P 2000 Methane in the Southern North Sea: low salinity inputs, estuarine removal and atmospheric flux; Global Biogeochem. Cycles 14 1205-1217.

van der Nat F W A, de Brouwer J F C, Middelburg J J and Laanbroek H J 1997 Spatial Distribution and Inhibition 
by Ammonium of Methane Oxidation in Intertidal Freshwater Marshes; Appl. Environ. Microbiol. 63(12) 4734-4740.

Verma A, Subramanian V and Ramesh R 2002 Methane emissions from a coastal lagoon: Vembanad Lake, West Coast, India; Chemosphere 47 883-889.
Wanninkhof R 1992 Relationship between wind speed and gas exchange over the ocean; J. Geophys. Res. 97 7373-7382.

Wanninkhof R, Ledwell J R and Broecker W S 1985 Gas Exchange Wind-Speed Relation Measured with Sulphur Hexafluoride on a Lake; Science 227 1224-1226. 